\title{
Pengaruh Jenis Pupuk dan Konsentrasi Benzyladenin (BA) Terhadap Pertumbuhan dan Pembungaan Anggrek Dendrobium Hibrida
}

\section{Effect of Fertilizer and Concentration Benzyladenine (BA) on The Growth and Flowering of Orchid Hybrid Dendrobium.}

\section{Badri Burhan}

Sekolah Tinggi Ilmu Perkebunan Bandar Lampung

J1. Z.A Pagar Alam No 17.A Raja Basa Bandar Lampung

e-mail: badriburhan08@gmail.com

\begin{abstract}
Dendrobium as ornamental plants that are used as cut flowers, potted plants, wreaths, garden ornament has a high economic value (due to the type, beauty, shape, texture, flower size, and rarity), has a broad market opportunities, sources of germplasm as mains to cross in order to get new varieties, and to cultivate them do not require large tracts of land. to get orchid production which is reached with good cultivation, one of them is by using fertilizers and growth regulators (PGR) to obtain growth and good flowering of orchids. This study was conducted to answer the following questions: (1) Which type of foliar fertilizer that can generate the best response to the growth and flowering of orchid Dendrobium, (2) how the effect of benzyladenine (BA) on the growth and flowering of orchid Dendrobium, (3) whether there is an interaction between foliar fertilizers and provision of benzyladenine (BA) to influence the growth and flowering of orchid Dendrobium. The research conducted in the greenhouse, Faculty of Agriculture, University of Lampung from January to June 2014. The experiments were carried out with a complete randomized block design with three replications. The treatments arranged in factorial (2x5). The first factor of 2 types of fertilizers, was (NPK 20-15-15) and (NPK 10-40-15). The second factor is the various concentrations of BA are: 0, 100, 200, 300, and $400 \mathrm{mg} / \mathrm{l}$. based on data and discussion of experimental results that have been raised, it can be concluded as follows: Gandasil fertilizer (NPK 20-15-15) and Hyponex (NPK 10-40-15), had no effect on the growth and flowering of plants Dendrobium hybrids indicated by a variable percentage of plants to germinate, the number of new shoots, the height of new shoots, the increase of leaf pseudo stem diameter, and the percentage of flowering plants. Application of benzyladenine (BA) on the concentration of 100-400 mg / l, can stimulate flowering orchid hybrid Dendrobium, which is indicated by an increase in the percentage of flowering from 60.50 to $64.83 \%$. Application of BA on the concentration of $100-400 \mathrm{mg} / \mathrm{l}$ had no effect on the percentage of ornamental plants whis have new sprout, and the number and the height of new shoots. There is no interaction between the two types of NPK (20-15-15 and 10-40-15), with concentrations of BA in influencing all observed variables.
\end{abstract}

Keywords: Dendrobium, Two kinds of completed fertelizers, Benzyladenine, flowering

Diterima : 15 Juli 2016, disetujui : 15 September 2016

\section{PENDAHULUAN}

Anggrek Dendrobium sangat digemari oleh masyarakat Indonesia, hal ini terlihat dari minat konsumen terhadap anggrek Dendrobim mencapai 34\%, anggrek Oncidium Golden Shower 26\%, Catleya 20\%, Vanda 17\%, dan anggrek lainnya 3\% (Direktorat jendral Pengolahan dan Pemasaran Hasil Pertanian, 2005). 

Badri, B : Pengaruh Jenis Pupuk dan Konsentrasi Benzyladenin (Ba) Terhadap Pertumbuhan...

Tanaman anggrek Dendrobium mempunyai masa juvenil yang panjang, yaitu antara dua sampai lima tahun, sehingga memerlukan waktu yang lama untuk berbunga ( Hee et al., 2007). Percepatan untuk pembungaan pada tanaman anggrek Dendrobium diperlukan untuk meningkatkan daya saing dan nilai jual serta untuk meningkatkan program pemuliaan nya.

Tanaman anggrek Dendrobium merupakan salah satu anggrek simpodial yaitu anggrek yang tumbuh melalui dua poros tumbuh, poros tumbuh horizontal yang indeterminate dan poros tumbuh vertikal yang determinate, yang berakhir dengan infloresens bunga (Yusnita, 2012). Bunga anggrek merupakan salah satu unsur terpenting untuk tanaman anggrek yang memiliki struktur dasar yang sudah baku, terdiri dari tiga kelopak (sepal) dan tiga tajuk bunga (petal). Salah satu petal berubah menjadi bibir bunga atau labellum. Bagian inilah yang menjadi ciri khas bunga anggrek sehingga membedakan dengan famili tanaman berbunga lainnya ( Sandra, 2006). Salah satu usaha untuk meningkatkan produksi bunga anggrek yang dapat dicapai yaitu dengan melakukan teknik budidaya yang efisien. Yaitu dengan penggunaan pupuk dan zat pengatur tumbuh (ZPT) untuk meningkatkan pembungaan anggrek yang efisien.

Berdasarkan hasil penelitian terdahulu, pembungaan pada tanaman anggrek Dendrobium dipengaruhi oleh beberapa faktor, yaitu: itensitas cahaya (Kataoka et al., 2004), temperatur, panjang hari atau fotoperiodesitas (Vaz et al., 2004), dan ZPT, terutama sitokinin atau geberelin (Bonhomme et al., 2000). Kualitas dan kuantitas pada produksi tanaman anggrek dapat ditingkatkan dengan mempercepat pertumbuhan dan pembungaan pada tanaman anggrek, melalui pemberian pupuk dan zat pengatur tumbuh (Gunawan, 2005). Di antara berbagai macam ZPT, salah satu jenis sitokinin yang sudah terdokumentasi dapat merangsang pembungaan pada anggrek, adalah benzyladenin (BA). BA memberikan efek konsisten pada induksi pembungaan anggrek Aranda Deborah, Dendrobium Louisae Dark dan Aranthera James Stone, juga dilaporkan memberi efek pembungaan pada anggrek monopodial (Hew dan Yong, 2004). BA pada konsentrasi 200 mg/l dapat memacu pembungaan pada Dendrobium Sonia 17 (Tee et al., 2008), Dendrobium Chao Praya Smile (Hee et al., 2007), Cymbidium nivio-marginatum Mak (Kostenyuk et al., 2007), dan Phalaenopsis Pink Leopard „Petra“e (Duan dan Yazawa., 1995).

Pupuk merupakan penyedia nutrisi bagi tanaman anggrek yang sangat penting. Media tanam untuk anggrek Dendrobium umumnya tidak dapat menyimpan dan menyediakan hara bagi tanaman, sehingga pemupukan yang rutin merupakan keharusan dalam budidaya tanaman anggrek. Pupuk majemuk baik berbentuk tepung (powder) maupun cair, yang dilarutkan dalam air dapat menyediakan unsur hara makro dan mikro yang dibutuhkan tanaman anggrek untuk pertumbuhan maupun perkembangannya. Istilah yang digunakan adalah pupuk daun, karena biasanya oleh petani tanaman anggrek, pupuk tersebut dilarutkan dalam air dan diberikan ke tanaman dengan disemprotkan ke bagian daun tanaman. Tanaman anggrek seperti tanaman lainnya memerlukan unsur hara makro dan unsur hara mikro. Unsur hara makro yang diperlukan tanaman adalah $\mathrm{N}$ (nitrogen), S (sulfur), P (fosfor), K (kalium), Ca (kalsium) dan Mg (magnesium). Unsurunsur mikro yang diperlukan tanaman antara lain $\mathrm{Cu}$ (tembaga), $\mathrm{Fe}$ (besi), $\mathrm{Mn}$ (mangan), Mo (molybdenum), B (boron), Zn (seng) dan lain-lain. Konsentrasi dan rasio unsur hara yang terkandung dalam pupuk sangat berpengaruh terhadap pertumbuhan tanaman anggrek Dendrobium. Pada tanaman anggrek Dendrobium berumur antara 1 tahun setelah diaklimatisasi, diharapkan sudah memasuki tahap remaja dan siap untuk dibungakan sehingga banyak memerlukan pupuk NPK dengan ukuran dosis tertentu.

Penelitian ini mempelajari dua faktor, yaitu jenis pupuk dengan kandungan NPK berbeda dan berbagai konsentrasi BA terhadap pertumbuhan dan pembungaan tanaman anggrek Dendrobium hibrida. Tujuan penelitian adalah membandingkan dua jenis pupuk, yaitu (NPK= $20: 15$ 15, dan (NPK= $10-40-15)$ dalam mempengaruhi pertumbuhan dan pembungaan Dendrobium hibrida, mempelajari pengaruh berbagai konsentrasi BA, dan interaksi antara jenis pupuk dengan konsentrasi BA terhadap pertumbuhan dan pembungaan Dendrobium hibrida. 


\section{METODE}

Penelitian dilaksanakan di rumah kaca, Fakultas Pertanian Universitas Lampung dari bulan Januari sampai dengan Juni 2014. Alat yang digunakan dalam percobaan ini berupa pot dengan diameter $12 \mathrm{~cm}$, hand sprayer volume $1000 \mathrm{ml}$, dan $500 \mathrm{ml}$, penggaris, selang air, gelas ukur, timbangan elektrik, spidol dan alat tulis. Bahan tanam yang digunakan adalah anggrek Dendrobium hibrida pada fase dewasa setinggi 15 $\mathrm{cm}$ dengan umur \pm 1 tahun sejak di aklimatisasi yang berasal dari nuseri anggrek di Malang Indonesia. (Hasanuddin orchid), pupuk Gandasil-D (NPK 20-15-15), Hyponex ( NPK 10-40-15), larutan BA, arang kayu, styrofoam dan Ditane M-45 (bahan aktif Mankozep 80\%).

Percobaan dilakukan dengan rancangan acak kelompok lengkap dengan 3 ulangan. Perlakuan disusun secara faktorial ( 2 x 5), faktor pertama 2 jenis pupuk, yaitu (NPK $20: 15: 15)$ dan (NPK $10: 40: 15$ ) dan faktor kedua adalah berbagai konsentrasi benziladenin (BA) yaitu : 0, 100, 200, 300 dan $400 \mathrm{mg} / \mathrm{l}$.

Persiapan pot dan media tanam. Pot yang akan digunakan, berdiameter $12 \mathrm{~cm}$. Media tanam yang digunakan yaitu arang kayu. Arang-arang yang besar dihancurkan terlebih dahulu, agar mudah untuk memindahkan tanaman dan media akan lebih padat, sehingga media lebih kuat untuk menopang tanaman anggrek.

Pemindahan tanaman anggrek (Repotting). Repotting atau pindah tanam dilakukan pada tanaman anggrek yang telah memasuki usia dewasa dengan menggunakan pot yang berukuran $12 \mathrm{~cm}$. Media tanam yang terdapat pada pot lama tetap digunakan namun ditambah media baru yaitu arang kayu. Setelah repotting tanaman diberi label perlakuan.

Pemupukan. Pemupukan merupakan kegiatan memberikan nutrisi atau unsur hara yang diberikan pada tanaman. Pemupukan bisa dilakukan melalui akar maupun daun. Pemupukan melalui akar dilakukan dengan cara memberikan pupuk pada media tanaman. Pemberian pupuk melalui daun biasanya dilakukan dengan penyemprotan pupuk pada permukaan daun.

Kebutuhan unsur hara pada setiap fase pertumbuhan tanaman anggrek berbeda- beda. Untuk anggrek yang masih pada fase pembibitan membutuhkan unsur hara nitrogen lebih tinggi, yaitu $60 \% \mathrm{~N}, 30 \% \mathrm{P}$, dan $10 \%$ K. Pupuk diberikan cukup sekali setiap minggu melalui daun selama fase pembibitan. Pada fase tanaman muda, kebutuhan nutrisi atau unsur haranya adalah $30 \% \mathrm{~N}, 30 \% \mathrm{P}$, dan $30 \% \mathrm{~K}$. Pemberian pupuk melalui daun cukup diberikan seminggu sekali, sedangkan pemupukan melalui akar dapat diberikan tiga minggu sekali. Kebutuhan pupuk untuk anggrek dewasa yang sudah memasuki fase generatif atau pembungaan adalah $10 \% \mathrm{~N}, 60 \% \mathrm{P}$, dan $30 \% \mathrm{~K}$. Pemupukan lewat daun diberikan seminggu sekali, sedangkan pemupukan lewat akar bisa diberikan tiga minggu sekali pada media tanam.

Pemupukan NPK (20-15-15) dan NPK (10-40-15) dilaku setiap minggu 1 kali dengan menggunakan hand sprayer. Penyemprotan dilakukan pada sore hari antara pukul 17.00-18.00, dengan $2 \mathrm{~g} / \mathrm{l}$. Sebelum dilakukan pemupukan pada pagi hari tanaman disiram terlebih dahulu, dan setelah dipupuk tidak dilakukan penyiraman selama 24 jam, volume penyemprotan pada setiap tanaman sebanyak 8-10 ml dan selama penelitian dilakukan 8 kali penyemprotan. Maka dosis pupuk setiap tanaman adalah $160 \mathrm{mg}$ atau $0,16 \mathrm{~g}$.

Pemberian Benziladenin (BA). Larutan dibuat dengan menimbang BA sebanyak 0,1.g, lalu diberikan $\mathrm{HCl} 1 \mathrm{~N}$ sebanyak $0,3 \mathrm{ml}$ hingga $\mathrm{BA}$ larut oleh $\mathrm{HCl}$. Kemudian dilakukan penambahan akuades dan ditera hingga volume akhir $1000 \mathrm{ml}$, pada tahap akhir diukur $\mathrm{pH}$ larutan diatur menjadi 5,6 menggunakan $\mathrm{pH}$ meter. Apabila pH kurang dari 5,6 maka perlu diteteskan $\mathrm{KOH}$ dan apabila $\mathrm{pH}$ lebih dari 5,6 maka perlu diteteskan $\mathrm{HCl}$ hingga $\mathrm{pH}$ mencapai 5,6. Volume semprot sebanyak. 8-10 ml/tanaman (8 kali semprot) yang diberikan sebanyak 8 kali pada minggu ke-1 hingga minggu ke-8 dengan interval waktu seminggu sekali. Pemberian BA dilakukan sesuai dengan konsentrasi yang ditetapkan yaitu 0 mg/l, 100 mg/l., 200 mg/l, 300 $\mathrm{mg} / \mathrm{l}$ dan $400 \mathrm{mg} / \mathrm{l}$. Dosis BA yang diberikan setiap tanaman.

Pemeliharaan. Pemeliharaan tanaman yaitu dengan melakukan penyiraman dan pengendalian hama dan penyakit. Penyiraman dilakukan setiap 1 hari sekali atau disesuaikan dengan kondisi cuaca.

196 Volume 16, Nomor 3, September 2016 
Pengendalian hama dan penyakit yaitu dengan menggunakan Dhitane M-45 dan pemberiannya dua minggu sekali.

Pengamatan. Pengamatan dilakukan setiap hari, dari minggu pertama setelah aplikasi perlakuan hingga akhir penelitian pada minggu ke 12, untuk 9 variabel, yaitu Persentase tanaman bertunas baru (\%), Jumlah tunas baru (tunas), Tinggi tunas baru $(\mathrm{cm})$, Diameter batang semu $(\mathrm{cm})$, Pertambahan jumlah daun (helai), Persentase tanaman berbunga (\%), Panjang malai bunga $(\mathrm{cm})$, Jumlah kuntum bunga per malai (kuntum), dan Diameter bunga terbesar (cm). Kemudian Data di setiap variabel di analisis ragamnya ( uji F), dan jika terdapat perbedaan nyata antara perlakuan maka di lanjutkan dengan pemisahan nilai tengah, untuk mengetahui perlakuan terbaik dengan uji BNT $0,05 \%$.

\section{HASIL DAN PEMBAHASAN}

Pemberian pupuk lengkap NPK yang komposisinya berbeda yaitu NPK( 20-15-15 dan 10-40-15, konsentrasi BA dan interaksi antar kedua faktor tersebut tidak mempengaruhi persentase tanaman bertunas baru, jumlah tunas baru dan tinggi tunas baru anggrek Dendrobium hibrida. Rata-rata persentase tanaman bertunas pada semua kombinasi perlakuan yang diuji berkisar antara 54-79\%, sedangkan kisaran jumlah tunas baru yang dihasilkan adalah 1-2 (helai), dan kisaran tinggi tunas baru adalah 24-30 (cm) (Tabel 1).

Tabel 1. Pengaruh komposisi NPK dan konsentrasi BA terhadap persentase bertunas, jumlah tunas baru dan tinggi tunas baru tanaman anggrek Dendrobium hibrida pada tiga bulan setelah aplikasi perlakuan pertama.

\begin{tabular}{ccccc}
\hline \multicolumn{2}{c}{ Perlakuan } & $\begin{array}{c}\text { Persentase Tanaman } \\
\text { Bertunas }(\%)\end{array}$ & $\begin{array}{c}\text { Jumlah Tunas Baru } \\
\text { (tunas) }\end{array}$ & $\begin{array}{c}\text { Tinggi Tunas Baru } \\
(\mathrm{cm})\end{array}$ \\
\hline \multirow{2}{*nnnnn}{ Komposisi NPK } & Konsentrasi BA (mg /l) & 58,33 & 1,00 & 24,79 \\
NPK 20-15-15 & 0 & 54,17 & 1,83 & 26,38 \\
& 100 & 79,17 & 1,91 & 26,33 \\
& 200 & 75,00 & 1,89 & 27,37 \\
NPK 10-40-15 & 300 & 66,67 & 2,10 & 25,59 \\
\hline & 100 & 58,33 & 1,07 & 27,43 \\
& 100 & 54,17 & 1,83 & 30,74 \\
& 200 & 62,50 & 2,44 & 24,63 \\
& 300 & 75,00 & 1,90 & 25,42 \\
& 400 & 79,17 & 2,14 & 25,85 \\
\hline
\end{tabular}

Pemberian NPK dengan komposisi yang berbeda juga tidak berpengaruh terhadap diameter batang semu, namun konsentrasi BA mempengaruhi diameter batang semu. Tidak terdapat interaksi antara komposisi NPK dengan konsentrasi BA dalam mempengaruhi diameter batang semu. Hasil uji BNT untuk pengaruh berbagai konsentrasi BA terhadap diameter batang semu ditunjukkan pada Diameter batang semu terbesar didapat pada perlakuan BA $100 \mathrm{mg} / \mathrm{l}$, sedangkan yang lebih kecil didapatkan pada perlakuan BA 200-400 mg/l. Tanpa BA, rata-rata diameter batang semu tak berbeda pada semua perlakuan BA yang Dicobakan (Gambar 1) 
Badri , B : Pengaruh Jenis Pupuk dan Konsentrasi Benzyladenin (Ba) Terhadap Pertumbuhan...

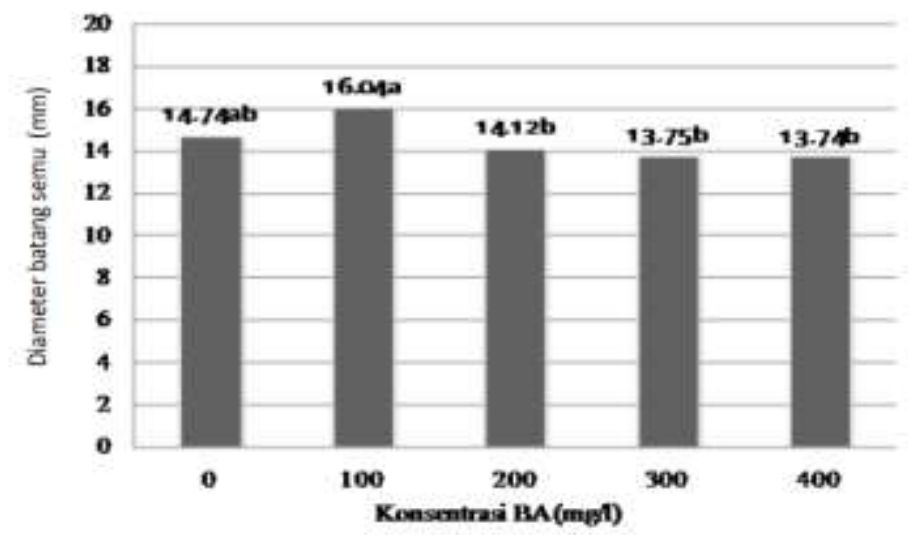

Gambar 1. Pengaruh berbagai konsentrasi BA terhadap diameter batang semu anggrek Dendrobium hibrida. Nilai tengah yang diikuti oleh huruf yang sama tidak berbeda berdasarkan uji BNT 0.05 .

Pemberian pupuk lengkap NPK yang komposisinya berbeda yaitu NPK( 20-15-15 dan 10-40-15) pada tanaman anggrek Dendrobium tidak mempengaruhi pertumbuhan pada perlakuan pupuk adalah 10,2 helai. Aplikasi BA pada konsentrasi $200 \mathrm{mg} / \mathrm{l}, 300 \mathrm{mg} / \mathrm{l}$ dan $400 \mathrm{mg} / \mathrm{l}$ meningkatkan jumlah daun baru dari 6,17 helai pada kontrol (tanpa BA) menjadi berturut-turut sebesar 12,03, 12,07 dan 13,26 helai. Ketiga nilai ini tidak berbeda satu sama lain (Gambar 2).

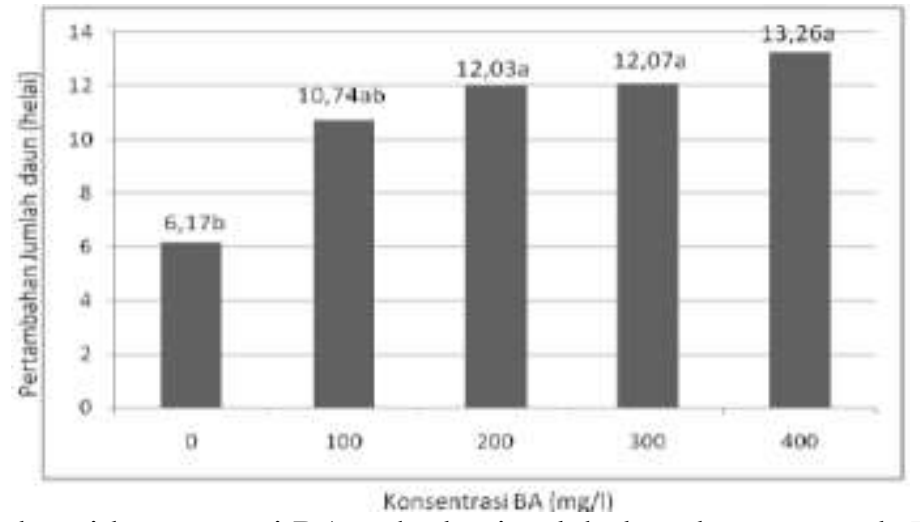

Gambar 2. Pengaruh berbagai konsentrasi BA terhadap jumlah daun baru anggrek Dendrobium hibrida.

Nilai tengah yang diikuti oleh huruf yang sama tidak berbeda berdasarkan uji BNT 0.05.

Hasil pengamatan menunjukkan bahwa aplikasi jenis pupuk NPK (20-15-15 dan 10-40-15 pada tanaman anggrek Dendrobium tidak mempengaruhi persentase tanaman anggrek berbunga. Persentase tanaman berbunga pada kedua perlakuan pupuk adalah sebasar 51,87 dan 53,53\%. Aplikasi BA mulai konsentrasi $100 \mathrm{mg} / \mathrm{l}, 200 \mathrm{mg} / \mathrm{l}, 300 \mathrm{mg} / \mathrm{l}$ dan $400 \mathrm{mg} / \mathrm{l}$ meningkatan persentase berbunga dari 8,5\% pada kontrol (tanpa BA) menjadi berturut-turut sebesar 62,67\%, 60,67\%, 64,83\% dan 60,50\%, dimana ke- empat nilai ini tidak berbeda nyata satu sama lainnya (Gambar 3).

Keragaman tanaman anggrek Dendrobium hibrida pada perlakuan tanpa BA (kontrol) dan perlakuan konsentrasi BA 100, 200, 300 dan 400 mg/l, pada umur 12 minggu setelah aplikasi pertama. Hampir semua tanaman anggrek Dendrobium hibrida yang tidak diberi BA (dari 24 tanaman) tidak berbunga, sedangkan pada perlakuan BA dari konsentrasi 100 sampai $400 \mathrm{mg} / \mathrm{l}$, tanaman anggrek Dendrobium hibrida berbunga dengan persentase $60-65 \%$. 


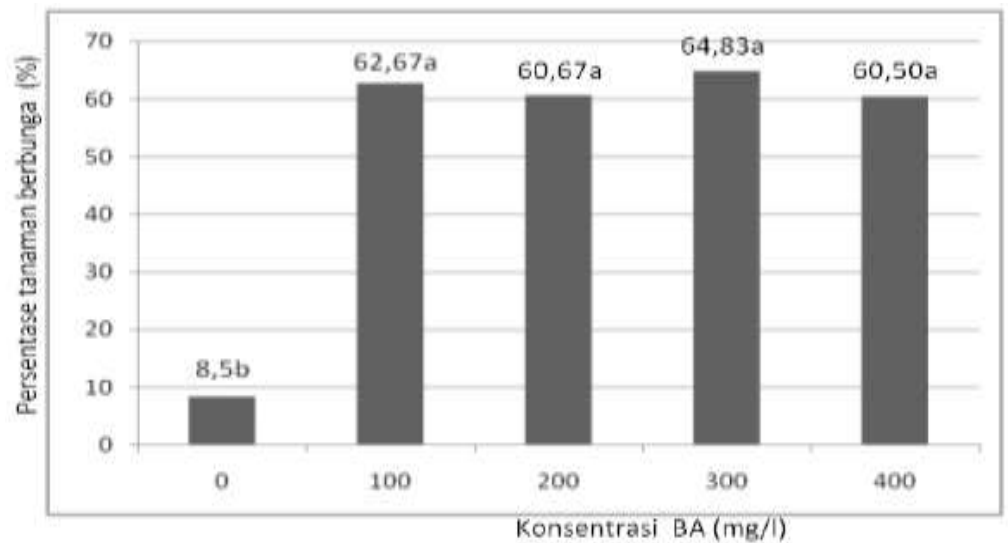

Gambar 3. Pengaruh pemberian berbagai konsentrasi BA terhadap persentase tanaman berbunga anggrek Dendrobium hibrida. Nilai tengah yang diikuti oleh huruf yang sama tidak berbeda berdasarkan uji BNT 0.05 .

Semua malai yang muncul pada penelitian ini adalah bunga pertama. Pada Gambar 4 terlihat beberapa malai bunga yang terbentuk ada yang berukuran yang sangat pendek dengan kuntum bunga yang berjumlah sedikit berkisar $1-5$ kuntum bunga.
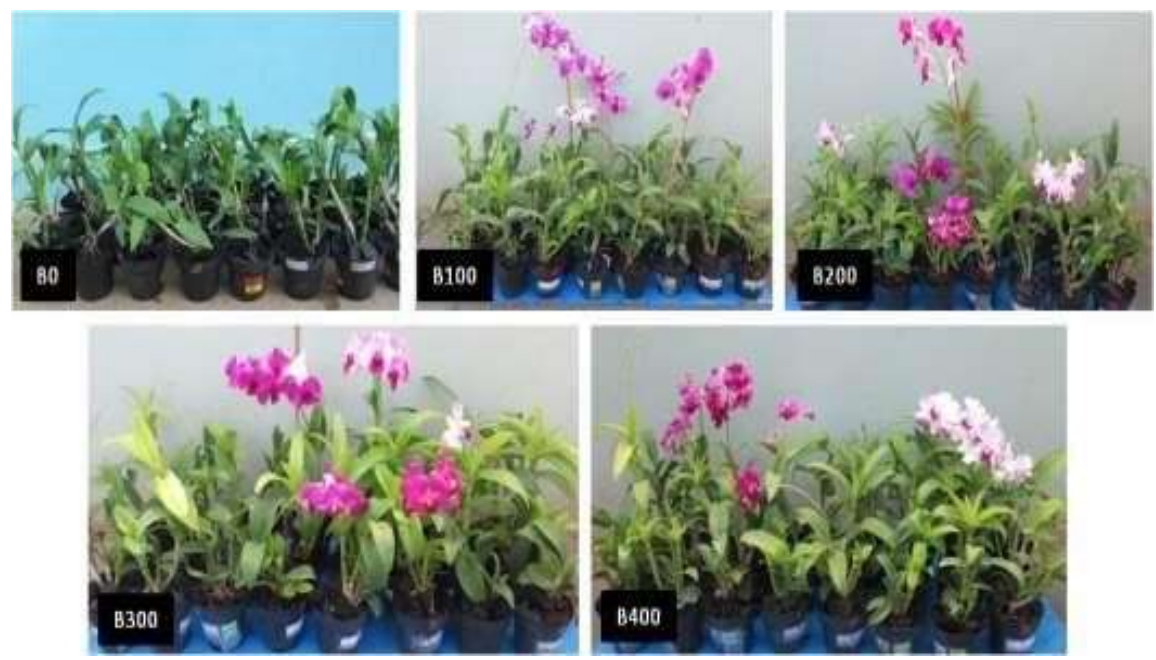

Gambar 4. Keragaan tanaman Dendrobium pada semua perlakuan yang dicobakan setelah 12 minggu sejak aplikasi BA pertama.

Tiga jenis Dendrobium hibrida digunakan sebagai kelompok dalam rancangan percobaan, yaitu Dendrobium Worawit Red, Dendrobium Emma White x Dendrobium lineale, Dendrobium. Mount Kelly Beauty x Dendrobium Hawaiian Molekaye. Dari analisis ragam terlihat bahwa beberpa karakter kuantitatif seperti persentase tanaman bertunas, tinggi tunas,diameter batang semu, pertambahan jumlah daun dan persentase tanaman berbunga menunjukkan perbedaan nyata.

Bentuk, warna dan corak kuntum bunga ketiga Dendrobium hibrida tersebut dapat dilahat pada Gambar 5. Mahkota bunga Dendrobium Worawit Red berbentuk bulat penuh, berwarna merah keunguan, bibir (labellum) sedikit lebih ungu dan warna sepal sama dengan mahkotanya. Kuntum bunga Dendrobium Emma White x Dendrobium lineale, berukuran lebih besar dibandingkan dengan Dendrobium Worawit Red, dengan mahkota bunga berbentuk bulat tidak penuh (semi bulat), mahkota dan sepalnya berwarna dominan putih dengan pinggir mahkota dan bagian tengah labellum bersemburat warna merah keunguan. 

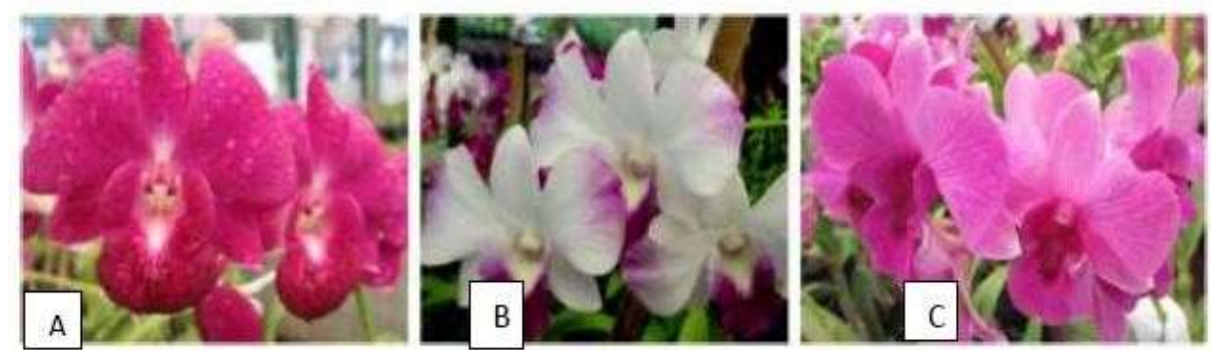

Gambar 5. Warna, bentuk dan corak bunga Dendrobium hibrida yang digunakan dalam penelitian ini: a. D Worawit Red; b. (D. Emma White x $D$. lineale) dan c. [D. Mount Kelly Beauty x (D. Mount Kelly Beauty x D. Hawaiian Molekaye)].

Kuntum bunga Dendrobium Mount Kelly Beauty x Dendrobium Hawaiian Molekaye, berukuran lebih besar dari pada kedua Dendrobium lainnya. Mahkota bunganya berbentuk bulat penuh, berwarna sama dengan petal nya, yaitu merah keunguan bergaris tipis. Beberapa karakter hortikultura kuantitatif ketiga jenis Dendrobium hibrida tersebut dapat dilihat pada Tabel 2.

Tabel 2. Perbedaan karakter hortikultura tiga jenis Dendrobium hibrida

\begin{tabular}{lccc}
\hline \multirow{2}{*}{ Karakter Kuantitatif } & \multicolumn{3}{c}{ Jenis Dendrobium hibrida } \\
\cline { 2 - 4 } & D.'Worawit Red' & $\begin{array}{c}\text { (D.Emma White x } D \\
\text { lineale })\end{array}$ & $\begin{array}{c}{[D \text {. Mount Kelly Beauty x }} \\
(D . \text { Mount Kelly Beauty x } \\
D \text { Hawaiian Molekaye) }]\end{array}$ \\
\hline Persentase Tanaman Bertunas (\%) & 87,5 & 60 & 51,2 \\
Rata-rata jumlah tunas baru & 1,95 & 1,6 & 1,91 \\
Rata-rata tinggi tunas baru (cm) & 20,75 & 28,85 & 29,76 \\
Jumlah daun baru (helai) & 13,8 & 9,44 & 9,41 \\
Persentase tanaman berbunga (\%) & 41,3 & 45,2 & 67,8 \\
Diameter batang semu (mm) & 13,73 & 15,22 & 14,48 \\
Panjang malai bunga (cm) & 22,38 & 35 & 39,33 \\
Diameter kuntum bunga (cm) & 6 & 7,63 & 8,2 \\
Jumlah kuntum per malai & 10 & 9 & 11 \\
\hline
\end{tabular}

Pada Tabel 2 terlihat bahwa Dendrobium Worawit Red, mempunyai persentase bertunas baru yang lebih tinggi dari pada dua Dendrobium lainnya, sedangkan Dendrobium Mount Kelly Beauty $\mathrm{x}$ (Dendrobium Mount Kelly Beauty x Dendrobium Hawaiian Molekaye), menujukkan persentase tanaman berbunga yang paling tinggi dengan jumlah kuntum bunga paling banyak dan malai bunga terpanjang, sehingga lebih sesuai untuk bunga potong. Dua jenis Dendrobium hibrida lainnya, yaitu Dendrobium Worawit Red, Dendrobium Emma White x Dendrobium Lineale, tampaknya lebih sesuai untuk bunga pot.

Aplikasi pupuk lengkap NPK (20-15-15, 10-40-15) memberikan pengaruh lebih baik pada pertumbuhan dan perkembangan tanaman anggrek Dendrobium hibrida yang ditunjukkan oleh rata-rata dari semua variabel pengamatan persentase tanaman bertunas, jumlah tunas baru, tinggi tunas baru, diameter batang semu, jumlah daun baru, dan persentase tanaman anggrek berbunga dari jenis pupuk lengkap yang dicobakan. Hal ini diduga pupuk lengkap (Gandasil) mengandung N 20\%, P 15\%, K 15\%, unsur hara makro dan mikro yang saling melengkapi satu sama lainnya, dan tambahan unsur hara mikro $\mathrm{Mn}, \mathrm{B}, \mathrm{Cu}, \mathrm{Co}, \mathrm{Zn}$ serta adanya vitamin untuk pertumbuhan tanaman seperti aneunrin, laktoflavin, nicotinic acid amide (PT Kalatham), sedangkan pupuk lengkap (Hyponex) mengandung N 10\%, P 40\% K 15\% dan tambahan unsur mikro B, Ca, Co, Cu, Fe, Mg, Mn, Mo, S dan Zn (PT Paramanira).

Pada fase pertumbuhan vegetatif perlu diberikan pupuk dengan kandungan $\mathrm{N}$ yang tinggi, karena unsur tersebut merupakan bahan utama untuk menyusun protein yang dibutuhkan dalam pembelahan sel (Sandra, 2006). Pada tanaman anggrek muda pemberian pupuk dengan kandungan $\mathrm{N}$ tinggi akan memberikan pertumbuhan yang lebih baik dan cepat, karena nitrogen adalah bahan utama penyususun asam 
amino, protein, asam nukleat, berbagai enzim dan sebagai zat penghijau daun. Pada fase generatif diperlukan hara fosfor $(\mathrm{P})$ tinggi dapat merangsang proses pembungaan. Pada fase generatif, kebutuhan unsur $\mathrm{P}$ tinggi, karena unsur ini berperan dalam perangsangan bunga dan tumbuhnya biji. Unsur $\mathrm{P}$ juga berperan dalam merangsang pertumbuhan akar dan bibit. Kekurangan unsur P akan menyebabkan ujungujung daun menjadi coklat, perakaran tidak subur, bunga tidak membuka sempurna dan tangkai bunga mengering sebelum bunga mekar.

Secara umum dari hasil penelitian menunjukan bahwa anggrek dendrobium dapat tumbuh dan berkembang dengan baik pada pemberian pupuk lengkap NPK 20-15-15 dan NPK 10-40-15. Berdasarkan hasil penelitian terdahulu, pembungaan pada tanaman anggrek Dendrobium hibrida dipengaruhi oleh beberapa faktor, yaitu: Intensitas cahaya (Kataoka et al., 2004). Temperatur, panjang hari atau foto-eriodesitas (Vaz et al.,2004). Zat pengatur tumbuh, terutama sitokinin, geberelin (Bonhomme et al., 2000).

Pemupukan adalah salah satu kunci keberhasilan yang utama dalam budidaya tanaman anggrek Dendrobium hibrida. Pemupukan pada tanaman anggrek dapat dibagi menjadi dua, yaitu fase pertumbuhan vegetatif dan fase pertumbuhan generatif. Fase pertumbuhan vegetatif adalah periode pertumbuhan anggrek dari semaian hingga menjadi tanaman anggrek muda, sedangkan fase generatif adalah periode pertumbuhan tanaman anggrek dewasa yang telah siap untuk berbunga (Sandra, 2006).

Lingga dan Marsono (2001) menyatakan bahwa pupuk mengandung unsur hara makro dan unsur hara mikro dengan konsentrasi yang berbeda-beda. Namun secara umum hara yang dominan dalam pupuk NPK adalah unsur hara makro dengan tambahan beberapa unsur hara mikro. Unsur hara mikro adalah zat yang tidak banyak diperlukan oleh tanaman tetapi turut menentukan pertumbuhannya. Pemupukan yang dilakukan melalui daun memiliki beberapa keuntungan yaitu dapat memberikan hara yang sesuai kebutuhan tanaman, kearutan yang lebih baik dibandingkan dengan pupuk akar, serta pemberiannya dapat diatur sesuai pertumbuhan tanaman.

Menurut Havlin et al., (1999) dalam Tirta (2006), pemberian dosis pupuk N yang semakin meningkat mengakibatkan peningkatan ketersediaan unsur $\mathrm{N}$ dalam tanah, yang memacu aktifitas fotosintesis dan pertumbuhan vegetative tanaman. Yusnita, 2010 mengatakan bahwa pada saat tanaman dewasa dan mulai berbunga, proporsi pemberian pupuk dengan kandungan $\mathrm{P}$ dan $\mathrm{K}$ tinggi perlu ditingkatkan agar perkembangan bunga tidak terganggu. Salisbury dan Ross (1995), menyatakan bahwa unsur hara makro yang berperan dalam pembentukan bunga secara langsung adalah fosfor dan kalium, sedangkan unsur hara mikro yang membantu dalam proses pembungaan adalah mangan. Mangan membantu dalam proses metabolisme seperti pembungaan. Perhatikan secara khusus harus diberikan kepada penerapan pupuk yang tepat. Waktu dan rotasi dalam aplikasi pupuk dengan nitrogen yang tinggi atau kalium tinggi dan atau fosfat. Beberapa tanaman anggrek Aranda telah diobservasi mengalami perubahan dan tunas bunga muda menjadi tunas yang vegetatif setelah penerapan nitrogen yang tinggi. Jelas, ratio $\mathrm{C}$ dan $\mathrm{N}$ perlu diperhatikan selama pembungaan anggrek (Hew dan Yong, 2004).

Hasil penelitian pada pertumbuhan dan pembungaan pada perlakuan yang disemprotkan terhadap tanaman anggrek Dendrobium hibrida, dengan larutan BA pada konsentrasi $100 \mathrm{mg} / \mathrm{l}$ setiap minggu yang dilakukan penyemprotan selama 8 minggu, mampu menghasilkan diameter batang semu pada tanaman anggrek Dendrobium hibrida yang terbesar terlihat pada konsentrasi BA $100 \mathrm{mg} / \mathrm{l}$, yaitu $16,04 \mathrm{~cm}$, sedangkan dari hasil pengamatan pada diameter batang semu yang lebih kecil terdapat pada perlakuan BA 200-400 mg/l, yaitu $13,75 \mathrm{~cm}$. Hal ini diduga dalam pemberian BA $100 \mathrm{mg} / \mathrm{l}$ sudah mencapai titik maksimum, sehingga hormon yang ada dalam jaringan tanaman seimbang terutama nisbah sitokinin dan ausin dalam kondisi yang ideal untuk memacu pertumbuhan dan perkembangan tanaman. Hew dan Yong (2004) mengemukakan, bahwa dalam pemberian BA pada konsentrasi $200 \mathrm{mg} / \mathrm{l}$ dapat meningkatkan pembungaan pada tanaman anggrek simpodial. 
Badri , B : Pengaruh Jenis Pupuk dan Konsentrasi Benzyladenin (Ba) Terhadap Pertumbuhan...

Pemberian BA untuk tanaman menghasilkan tunas vegetatif, sehingga pemberian BA harus tepat pada waktunya. Pertumbuhan tanaman anggrek dapat dipacu apabila nisbah sitokinin terhadap auksin pada jaringan tanaman anggrek tinggi, fungsi utama sitokinin adalah untuk memacu pembelahan sel (Salisbury dan Ross,1995). Hasil percobaan yang dilakukan juga menunjukkan bahwa, pemberian BA mulai dari 200 $\mathrm{mg} / 1$ menghasilkan jumlah daun baru yang lebih banyak dari pada kontrol maupun perlakuan $100 \mathrm{mg} / 1 \mathrm{BA}$. Peningkatan konsentrasi benziladenin BA menjadi 300 dan $400 \mathrm{mg} / \mathrm{l}$ dapat menghasilkan pertambahan jumlah daun baru yang tidak berbeda dengan perlakuan $200 \mathrm{mg} / 1 \mathrm{BA}$. Maka dengan peningkatan konsentrasi BA 200 mg/1 merupakan konsentrasi maksimum dalam meningkatkan pertambahan jumlah daun. Dari hasil penelitian ini juga, sejalan dengan hasil penelitian Nambiar et al. (2012) yang mengatakan bahwa perlakuan benziladenin BA dapat meningkatkan jumlah daun baru. Tanaman yang disemprotkan BA dengan konsetrasi $200 \mathrm{mg} / \mathrm{l}$ menghasilkan jumlah daun baru terbanyak pada tanaman anggrek Dendrobium Angel White. Hasil penelitian juga menunjukkan, bahwa pertambahan jumlah daun baru berkaitan dengan jumlah tunas baru, hal ini berarti pertambahan jumlah daun baru disebabkan oleh jumlah tunas baru yang terbentuk oleh tanaman.

Berdasarkan dari hasil penelitian, bahwa penyemprotan pada tanaman anggrek Dendrobium hibrida, dengan larutan BA pada konsentrasi $100 \mathrm{mg} / 1$ setiap minggu selama 8 minggu, dapat meningkatkan pembungaan atau munculnya infloresens bunga, dari 8,5\% pada kontrol tanpa BA menjadi 62,67\%. Dari hasil pengamatan pada pemberian BA pada konsentrasi yang lebih tinggi, yaitu 200, 300 dan $400 \mathrm{mg} / 1$ persentase tanaman anggrek Dendrobium hibrida, yang berbunga lebih besar, yaitu 60,67\%, 64,83\% dan 60,50\%. Dari data ini terlihat bahwa pemberian konsentrasi BA $100 \mathrm{mg} / 1$ tampaknya merupakan konsentrasi maksimum untuk meningkatkan pembungaan pada Dendrobium hibrida, karena peningkatan konsentrasi BA hingga $400 \mathrm{mg} / 1$ tidak menghasilkan perbedaan yang signifikan pada persentase tanaman berbunga. Hal ini sesuai dengan hasil penelitian Blanchard dan Runkle (2008), menyatakan bahwa pemberian BA bertanggung jawab terhadap perangsangan pembungaan pada anggrek Phalaenopsis dan Doritaenopsis. Wu dan Chang (2012) juga menyatakan bahwa BA memiliki porsi terbesar untuk merangsang pembungaan pada tanaman anggrek Phalaenopsis. Nambiar et.al. (2012) juga melaporkan bahwa pemberian BA mampu mampu meningkatkan pembungaan, dari hasil penelitian mereka juga menyatakan bahwa pada konsentrasi $200 \mathrm{mg} / 1$ BA dapat menghasilkan persentase tanaman berbunga yang paling tinggi pada tanaman anggrek Dendrobium Angel White.

ZPT adalah senyawa organik bukan hara, dalam konsentrasi rendah dapat mempengaruhi pertumbuhan dan perkembangan tanaman (Yusnita, 2011). ZPT ini dapat membantu pertumbuhan pada tanaman, metabolisme tanaman dan kegiatan tanaman lainnya, sehingga dapat berpengaruh terhadap perkembangan jaringan tanaman dan organnya.

Jika energi tersedia, tetapi unsur hara kurang, anggrek tidak akan berbunga. Energi yang lemah hanya dapat menarik nitrogen, akibatnya tanaman akan tetap tumbuh vegetatif dan tidak akan menghasilkan bunga (Sutiyo dan Sarwono, 2006). BA merupakan salah satu sitokinin sintetik yang terkenal, perannya dalam tumbuhan adalah untuk mengtur pembelahan sel, pembentukan organ pembesaran sel dan organ, pencegahan kerusakan klorofil, pembentukan kloroplas, penundaan senesens, pembukaan dan penutupan stomata, serta perkembangan mata tunas dan pucuk (Harjadi, 2009). Berbagai macamnya efek sitokinin menunjukkan bahwa senyawa tersebut mungkin mempunyai beberapa macam mekanisme kerja dalam jaringan yang berbeda, namun secara sedarhana diduga bahwa satu efek utama yang umum sering diikuti oleh sejumlah efek sekunder, yang bergantung pada keadaan fisiologis sel sasaran (Salisbury dan Ross, 1995).

BA mempunyai struktur yang serupa dengan kinetin, BA sangak aktif dalam mendorong pertumbuhan kalus. Sitokinin mempengaruhi berbagai proses fisiologis di dalam tanaman. Aktifitas yang utama adalah mendorong pembelahan sel dan aktifitas ini yang menjadi kriteria utama untuk mengolongkan suatu zat ke 
dalam sitokinin. Sitokinin memperlambat proses penghancuran butir-butir klorofil pada daun yang terlepas dari tanaman (degached leaves) dan memperlambat proses senecence pada daun, buah dan organ-organ lainnya. Pengaruh sitokini pada berbagai proses semua diduga pada tingkat pembuatan protein mengingat kesamaan struktur sitokinin dengan adenine yang merupakan komponen dari DNA dan RNA (Wattimena, 1988).

Hasil penelitian yang dilakukan, juga menunjukkan bahwa pemberian BA tidak mempengaruhi persentase tanaman bertunas, jumlah tunas baru, dan tinggi tunas baru, hal ini berarti perlakuan benziladenin (BA) yang diberikan tidak memberikan respon yang berbeda pada persentase tanaman bertunas, jumlah tunas baru maupun tinggi tunas baru pada tanaman anggrek Dendrobium hibrida yang diteliti.

\section{KESIMPULAN}

Berdasarkan data hasil dan pembahasan dari percobaan yang telah dikemukakan, dapat disimpulkan bahwa jenis pupuk lengkap Gandasil (NPK 20-15-15) dan Hyponex (NPK 10-40-15), tidak berpengaruh terhadap pertumbuhan dan pembungan tanaman anggrek Dendrobium hibrida yang di tunjukkan oleh variabel persentase tanaman bertunas, jumlah tunas baru, tinggi tunas baru, pertambahan jumlah daun diameter batang semu, dan persentase tanaman berbunga ; Aplikasi BA dari konsentrasi $100-400 \mathrm{mg} / \mathrm{l}$, dapat merangsang pembungaan tanaman anggrek Dendrobium hibrida, yang di tunjukkan oleh peningkatan persentase pembungaan dari 60,50 - 64,83 \% ; Aplikasi BA $100-400 \mathrm{mg} / \mathrm{l}$ tidak berpengaruh terhadap persentase tanaman bertunas baru, jumlah tunas baru dan tinggi tunas baru ; Tidak terdapat interaksi antara dua jenis pupuk NPK (20-15-15 dan 10-40-15), dengan konsentrasi BA dalam mempengaruhi semua variabel yang diamati.

\section{SARAN}

Dari hasil penelitian yang dilakukan, dapat disarankan untuk melakukan penelitian yang sama pada tanaman anggrek dewasa yang siap untuk berbunga dengan menggunakan dua jenis pupuk majemuk yang memiliki kandungan $\mathrm{P}$ dan $\mathrm{K}$ lebih tinggi, dan frekuensi pemberian $\mathrm{BA}$ diturunkan, untuk dapat merangsang pertumbuhan dan pembungaan tanaman anggrek Dendrobium hibrida.

\section{DAFTAR PUSTAKA}

Blanchard, M.G. E.S. Runkle. 2008. Benzyladenine promotes flowering in Doritaenopsis and Phalaenopsis Orchids. J Plant Growth Regul. 27: 141-150.

Bonhomme, F., Kurz, B., Melzer, S., Bernier, G., Jacqmard, A. 2000. Cytokinin and gibberellin activate SaMADS A, a gene apparently involved in regulation of the floral transition in Sinapsi alba. - Plant J. 24: 103-111.

Direktorat Jendral Pengolahan dan Pemasaran Hasil Pertanian. 2005. Road Map Pascapanen dan Pemasaran Anggrek 2005-2010. http://agribisnis.deptan.go.id/. Diakses pada tanggal 24 Oktober 2009.

Duan, J.X. dan S. Yazawa. 1995. Induction precocious flowering and seed formation of Donella Tiny (Doritis pu/cherrima x Kingiella phflppinensis) in vitro and in vivo. ActaHort 397: 103-110.

Gunawan, LW. 2005. Budidaya Anggrek. Penebar Swadaya. Jakarta. 91 hlm.

Harjadi, S. S. 2009. Zat Pengatur Tumbuh. Penebar Swadaya. Jakarta. 76 hlm.

Hee, K.H. C.S.,Loh., H.H.Yeoh. 2007. In Vitro flowering and rapid in vitro embcyo production in Dendrobium Chao Praya Smile (Orchidaceae). Plant Cell Report 26: 2055-2062. 
Badri, B : Pengaruh Jenis Pupuk dan Konsentrasi Benzyladenin (Ba) Terhadap Pertumbuhan...

Hew, C. S. and J. W. H. Yong. 2004. The Physiology ofTropical Orchids in Relation to The Industry, Second Edition. World Scientific.370 P.

Kataoka K. K. Sumitomo. dan K. Kawase. 2004. Change in sugar content of Phalaenopsis leaves before floral transition. Sci Hort 102: 121-132.

Konstenyuk I, B.J. Oh dan F.S. So. 1999. Induction of Early flowering in Cymbidium niveo-marginatum Mark in vitro. Plant Cell Rep 19:1-5

Lingga, P. dan Marsono. 2001. Petunjuk Penggunaan Pupuk. Penebar Swadaya. Jakarta. 163 hlm.

Nambiar,N., C.S. Tee dan M. Mahmood. 2012. Effect of6- Benzylaminopurine on flowering of a Dendrobium orchid. AJCS 6(2): 225-231.

PT Kalatham (Distributor Pupuk Gandasil). Pupuk Daun yang Lengkap dan Sempurna. Leaflet. Jakarta. $1 \mathrm{hlm}$.

PT Paramanira (Distributor Pupuk Hyponex). Penunjang Sarana Pertamanan dan Pertanian Yang Efektif Hyponex. Leaflet. Jakarta.1 hlm.

Salisbury,F.B., dan C. W. Ross. 1995. Fisiologi Tumbuhan, Jilid 3. Penerbit ITB Bandung. 343 him.

Sandra, E. 2006. Membuat Anggrek Rajin Berbunga. PT AgroMedia Pustaka. Jakarta. 86 him.

Tee, C.S., M., Maziah, dan C.S.,Tan. 2008. Induction of in vitro flowering in the orchid Dendrobium Sonia 17. Bioi Plantarum 52(4): 723-726.

Tirta, I. G. 2006. Pengaruh Beberapa Jenis Media Tanam dan Pupuk Daun terhadap Pertumbuhan Vegetatif Anggrek Jamrud (Dendrobium macrophyllum A. Rich.). Jurnal Lembaga llmu Pengetahuan Indonesia. 7 (1): 81-84.

Vaz, A.P.A., Figueredo-Ribeiro RCL, dan Kerbauy GB. 2004. Photoperiod and temperatur effect on in vitro growt and flowering of P. Pusilla, an epiphytic orchid. Plan Physiol Bioch 42: 411-415.

Wattimena, G.A. 1988. Zat Pengatur Tumbuh Tanaman. Pusat Antar Universitas lnstitut Pertanian Bogor Bekerja Sarna dengan Lembaga Sumberdaya Informasi-IPB. 145 hlm.

Wu, P.H., dan D.C.N. Chang. 2012. Cytokinin treatment and flower quality in Phalaenopsis orchid: Comparing N-6 benzyladenine, kinetin and 2-isopentenyl adenin. African Journal of Biotechnology. 11(7):1592-1596.

Yusnita. 2010. Perbanyakan In VUro Tanaman Anggrek. Penerbit Universitas Lampung. Bandar Lampung. $128 \mathrm{hlm}$.

Yusnita. 2011. Pemuliaan Tanaman untuk MenghasilkanAnggrek Hibrida Unggul. Penerbit Lembaga Penelitian Universitas Lampung. Bandar Lampung. 171 blm.

Yusnita. 2012. PemuliaanTanaman untukMenghasilkanAnggrek Hibrida Unggul. Penerbit Lembaga Penelitian Universitas Lampung. Bandar Lampung. 